\title{
Do Quantity and Quality of Irradiance Influence Migration Behavior Motile Cells of the Green Alga, Ulva fasciata?
}

\author{
Hyun-Woung Shin', Han Seong Lee', Sang Mok Jung1, Min Kyu Choo'1, Ji Young Cho', \\ Kwang Soo Lee ${ }^{2}$, Celia M. Smith ${ }^{3}$ \\ ${ }^{1}$ Department of Life Science and Biotechnology, Soonchunhyang University, Asan City, South Korea \\ ${ }^{2}$ Department of Sport Science, Soonchunhyang University, Asan City, South Korea \\ ${ }^{3}$ Department of Botany, University of Hawaii, Honolulu, USA \\ Email: hwshin@sch.ac.kr
}

Received 3 July 2014; revised 22 August 2014; accepted 18 September 2014

Copyright (C) 2014 by authors and Scientific Research Publishing Inc.

This work is licensed under the Creative Commons Attribution International License (CC BY).

http://creativecommons.org/licenses/by/4.0/

(c) (i) Open Access

\begin{abstract}
Motile cells of the green alga, Ulva fasciata respond to the quantity and quality of irradiance simultaneously. The specific responses of motile cell types (gametes and spores) by irradiance influence migration behavior in coastal water environment. Gametes maximally aggregated at the highest white light intensity $\left(250 \mu \mathrm{mol} \cdot \mathrm{m}^{-2} \cdot \mathrm{s}^{-1}\right)$, while spores maximally aggregated in the dark $(0 \mu \mathrm{mol}$ $\mathrm{m}^{-2} \cdot \mathrm{s}^{-1}$ ) of this study. Gametes maximally aggregated in green irradiance over blue, red and dark while spore maximally aggregated in the dark. The results of quantity are spectral responses are likely to be underline the ecological success and physiological strategies in varied irradiance environments includes: 1) gametes respond to specific quantities and spectral irradiance; 2) spores respond negatively to quantity and quality of irradiance to enhance the probability of finding substratum; and 3) populations of adults that come from these motile cells behaviors. The specific quantities and spectral qualities of irradiance responses show specific ecological migration that can be attributed to photosynthesis under limiting irradiance in coastal waters for the motile cells of $U$. fasciata.
\end{abstract}

\section{Keywords}

Irradiance, Migration Behavior, Ulva fasciata, Gamete, Spore

\section{Introduction}

Photosynthetic organisms depend on light to survive. In the oceans, spectral composition, or quality, and the 
absolute levels of irradiance vary spatially and temporally [1]. Photobiology of motile phases largely unknown even for common reef algae where irradiance fields have been studied [2]. Some marine plants grow in habitats where irradiance levels appear distinctly limiting [3], aspects of dispersal in these environments by motile cells is unknown. The photobiology of marine algae is particularly interesting for several reasons including: 1) the diversity of photosynthetic pigments found among marine plantsindicates that greater physiological variation may be found among the photobiological responses of algae than among those of higher plants; 2) the natural irradiance field to which algae are exposed is more varied, both in quantity and spectral quality of irradiance levels, than in many terrestrial habitats; as yet described photobiological responses may have important consequences for growth and distribution in an underwater environment; 3) other physiological mechanisms of marine plants (i.e. needs of motile cells) may not be represented among typical land plants because of evolutionary distance between these kingdoms (Protista and Plantae). Studies that focus on physiological mechanisms of benthic may advance our understanding of the mechanisms that sustain communities of primary productivity in important deep water and shallow coastal ecosystems [4].

Motile cells of benthic algae are reported to react to irradiance as if it was a stimulus [5]. Gametes of Ulvafasciata and $U$. rigida respond positively to full spectrum photosynthetically active radiation (PAR), but their zygotes and spores do not [6]-[8]. Spores of these Ulvales exhibit negative responses to irradiance. This is an useful adaptation which increases the likelihood of finding a suitable substrate on which competent cells will attach [9]. For gametes, their positive (movement toward light) behavior enhances the numbers of gametes at an appropriate water column [9], thus increasing the likelihood of appropriate gamete encounters [10], and dispersal distances for resulting zygotes [11].

Habitats for benthic macroalgae range from the upper intertidal to the lower limit of the photic zone in all optical water types [12]. Benthic macroalgae responses to irradiance are of particular interest because irradiance conditions in coastal regions are likely to be more variable diurnally than in many other marine ecosystems. Many photomorphogenic responses in lower plants are recognized to be controlled by low fluence-sensitive photoreceptor(s) that have been suggested to control the vertical distribution or the phenological behavior (blue light photoreceptor) of marine macroalgae even in shallow coastal areas [13] [14]. Blue light effects mediated by a specific blue light photoreceptor, cryptochrome, a flavin, rhodopsin-like molecule, have also been reported in phytoplankton [1] [5] [14] [15]. Far-red/red light effects mediated by phytochrome have been implicated in a variety of algae processes such as stipe elongation in kelps [16], respiration in Dunaliella tertiolecta [17], and chlorophyll synthesis in Porphyraumbilicalis [18]. Green light effects however, remain unknown; no photoreceptor beside light harvesting for siphonein and siphonoxanthin containing green alga has been identified. The ecological relevance of these photoreceptors also remains unclear as the varying irradiance conditions in coastal waters likely limit higher and lower-energy spectral components (blue and red irradiance) from those waters far more than observed for terrestrial ecosystems.

An organism's response to irradiance also appears to be an ecological strategy [2]. Chromatic adaptation (genetic change) and acclimation (phenotypic change) are defined as long-term and short-term response to unfavorable irradiance environments. According to the chromatic adaptation and acclimation theory of Engelmann [19] algal zonation was first thought to be determined by the spectral changes in irradiance with depth. Algae were thought [20] [21], to complement changes in irradiance with the evolution of new pigments for light-harvesting. Alternatively, a series of studies [22] [23], show that Caulerpa cactoides and Ulva reticulata constitute asignificant fraction of the algal community from 20 to $35 \mathrm{~m}$ off the Pearson Island in the Great Australian Bight area. $U$. fasciata and $U$. reticulata have appeared at more than 51 sites of depth exceeding $128 \mathrm{~m}$ in subtropical region, Hawaii [24]. Green algae are generally held to be minor components of the algal community in dim irradiance environments; several studies however have shown that the proportion of the different pigments can be altered, with significant effects on absorbance properties, in accordance with the environmental conditions prevailing during growth and development. Yokohama et al. [25] have found that in certain members of the Ulvales, Cladophorales and Siphonocladales (Ulva japonica, Codium adhaerens, C. mamillosa, C. fragile, Ladophora wrightiana, aloniamacrophysa), the green light-harvesting pigment, siphonoxanthin, is found in thalli inhabiting deep or shaded sites, while lutein is found in algae inhabiting sunny sites in shallow water. Considerable alternations in spectral distribution of irradiance can be appeared in varied behaviors and habitats.

In any life history, the settlement and growth of a motile unicell into an adult multicellthallus is a dramatic sequence of ecological and developmental events. During this multi-step process, irradiance can be thought to 
stimulate photoreceptors. Although irradiance sustains metabolism and photomorphogenesis, perhaps its first and most important role for transient swimming stages is as a cue for site selection for an optimal location for that motile cell to settle [26] [27]. If gametes do not find the opposite mating strain, the next generation is unlikely. Even though developmental events and ecological cues are important to the ecological strategies of particular motile cells, the identification of factors that insure ecological success for these cell types has been largely ignored.

A recent study of photosynthesis in these life history stages has changed the way we view the physiology of motile cells for weedy green algal species [28] [29]. These motile cells maintained high levels of chlorophylls specific the maximum rate of photosynthesis (Pmax) and respiration (R), as well as requiring substantial irradiance levels to compensate and to saturate photosynthesis (Ic and Ik respectively) when compared with measures for parental thalli. For gametes of $U$. fasciata, Ic $=99.5 \mu \mathrm{mol} \cdot \mathrm{m}^{-2} \cdot \mathrm{s}^{-1}, \mathrm{Ik}=288.3 \mu \mathrm{mol} \mathrm{m} \mathrm{m}^{-2} \cdot \mathrm{s}^{-1}, \mathrm{Pmax}=1.44$ $\mu \mathrm{mol} \mathrm{O} \mathrm{mg}^{-1} \mathrm{chl} a+b \mathrm{~min}^{-1}$ and $\mathrm{R}=1.16 \mu \mathrm{mol} \mathrm{O}_{2} \mathrm{mg}^{-1} \mathrm{chl} a+b \min ^{-1}$; for spores of this species, Ic $=61.5 \mu \mathrm{mol}$ $\mathrm{m}^{-2} \cdot \mathrm{s}^{-1}, \mathrm{Ik}=172.6 \mu \mathrm{mol} \cdot \mathrm{m}^{-2} \cdot \mathrm{s}^{-1}$, Pmax $=1.18 \mu \mathrm{mol} \mathrm{O} \mathrm{mg}^{-1} \mathrm{chl} a+b \min ^{-1}$ and $\mathrm{R}=0.80 \mu \mathrm{mol} \mathrm{O} \mathrm{mg}^{-1} \mathrm{chl} a+b$ $\mathrm{min}^{-1}$. Additionally, the ratio of Pmax to $\mathrm{R}$ for gametes and spores of $U$. fasciata are significantly different from those of parental thalli (Pmax: $\mathrm{R}$; gametes $=1.44$, spores $=1.58$, adults $=4.78$ to 5.53 ) because of high $\mathrm{R}$ rates. Net photosynthetic performance may be the most important ecophysiological factor relating to cell longevity in planktonic assemblages as these unicells lack york sacs or feeding mechanisms of invertebrate larvae. Cells that are able to respond to irradiance in this ecologically relevant and photosynthetically important range are more likely to be successful. The respiratory costs and photosynthetic benefits of motile during site selection have been clarified more clearly from the study of Beach et al. [30], but still little is known of a cell's ability to respond to the quantity and spectral quality of irradiance, as a cue for proper location in an ecological setting.

The objective of this work is to extend earlier reports of phototaxis among motile cells of Ulva fasciata and even if examine mechanistic bases for abilities of motile cells to select irradiance as a character of a site appropriate for long term ecological success. The following questions are addressed: 1) Do cells respond to the intensity of ecologically relevant levels full spectrum irradiance? and 2) Do cells respond to spectral components of irradiance within ecological relevant levels of irradiance?

\section{Material and Methods}

\subsection{Sampling and Estimates of Motile Cells}

Thalli of Ulva fasciata Delile materials for this investigation were collected daily at Ka'alawai Beach (tide height of site approximately +0.2 feet) from the south coast of O'ahu Island in Hawai'i. Whole thalli of $U$. fasciata were collected randomly and transported to a laboratory in a plastic bag with seawater. All plant surfaces were cleaned several times with a soft brush in $0.2 \mu \mathrm{m}$ filtered seawater. The material was blotted dry, separated, and individual plants were placed in dry Petri dishes under $50 \mu \mathrm{mol} \mathrm{m} \mathrm{m}^{-2} \cdot \mathrm{s}^{-1}$ of fluorescent lights at room temperature $\left(19.5^{\circ} \mathrm{C}\right)$. Twelve hours later the thalli were barely covered with filtered seawater (approximately 30 $\mathrm{ml})$. This treatment led to the release of motile cells typically as a dense suspension of cells.

\subsection{Motile Cells Density}

Motile cells from initial suspensions were counted using a random field method [31]. Motile cell density in the sample was calculated using the following formula:

$$
\text { No. } / \mathrm{ml}=\mathrm{C} \times \mathrm{V} \times(\mathrm{A} \times \mathrm{D} \times \mathrm{F} \times \mathrm{Dil})^{-1}
$$

A is the area of field $\left(0.04 \mathrm{~mm}^{2}\right), \mathrm{C}$ is number of motile cells counted, $\mathrm{D}$ is depth of the field $(1.0 \mathrm{~mm}), \mathrm{F}$ is number of fields counted, $\mathrm{V}$ is volume of Sedgwick-Rafter (S-R) chamber $\left(1000 \mathrm{~mm}^{3}\right)$ and Dil is dilution factor ( 0.98 for $2 \%$ formalin). Counting and the identification of motile cells were accomplished at $200 \times$ and $1000 \times$ magnification with phase contrast microscopy (Olympus model BH-2). One ml aliquots of spores were preserved with one $\mathrm{ml}$ of $4 \%$ buffered formalin in vials $(4 \mathrm{ml})$ for the determination of cell density. One $\mathrm{ml}$ samples were removed from vials with a pipette and transferred to an S-R chamber and covered with a coverslip. Before proceeding with a count, each S-R chamber sat undisturbed for at least $2 \mathrm{~h}$ to permit cells to settle into one plane for easier observation and counting. After exposure to irradiance, aggregating gametes or spores were gently 
collected in $1 \mathrm{ml}$ volumes from illumination portions of petri dish using a modified syringe with a $1.4 \mathrm{~cm}$ diameter opening. This modified syringe was held perpendicular to the fiber optic cable providing illumination. The total number of motile cells was counted to allow determination for the percentage of motile cell aggregating in experimental portions of the petri dish. Three replicates were run in each section of experiments, and two whole sets of experiments were run to repeat the entire test. All procedures and runs were conducted in near absolute darkness in a functional darkroom. Approximate speed of motile cells was calculated by based on measuring distance between illumination and central area of petri dish.

\subsection{Experimental Design, Light Source and Radiation Measurement}

Three circles, each with a diameter of $2 \mathrm{~cm}$, were cut into the top of black wooden stage box (H:19 $\times$ W:21 $\times$ L:22 cm) (Figure 1). These three holes were each connected to a fiber optic light pipe (Dolan-Jenner Inc., Model BXS224, Length: $30 \mathrm{~cm} \times 1.4 \mathrm{~cm}$ diameter), which was in turn connected to a white light (tungsten lamp) microscope illuminator (Cole Parmer, Model: 9741-50). Fiber optic light pipes were selected for their light-deli-

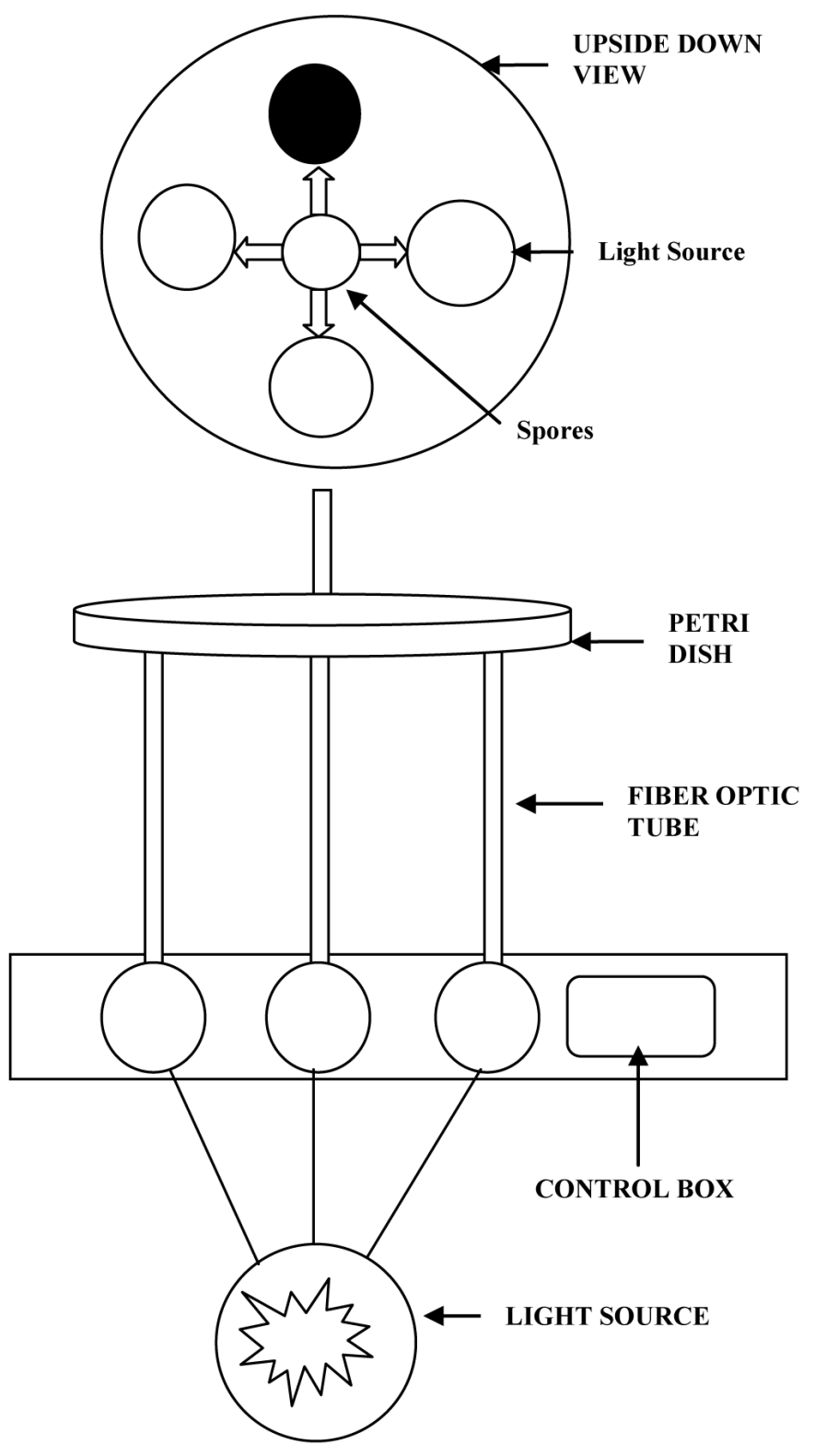

Figure 1. Illustration showing test system apparatus. 
vering capability and for their constant temperature. This connection was made more effective by surrounding the gap between the illuminator output and the three fiber optic light pipes with aluminum foil to reduce any light leakage. A $5 \mathrm{ml}$ aliquot of motile cells $\left(1.1 \times 10^{-4}\right.$ to $6.4 \times 10^{-6}$ motile cells $\left.\mathrm{ml}^{-1}\right)$ released from healthy thalli of $U$. fasciata was gently introduced into a petri dish (V: $80 \mathrm{ml}, \mathrm{H}: 1.5 \times 8.5 \mathrm{~cm}$ diameter) filled with 15 $\mathrm{ml}$ of filtered seawater through a plastic pipette that was vertically attached to the center of the petri dish cover. This technique placed the motile cells into a central area that was equidistant from each irradiance source. The circular area of illumination from the fiber optic cables for each irradiance treatment was $1.54 \mathrm{~cm}^{2}$. The lownoise illuminator (Cole Parmer Instrument Co., Model 9741-50) was equipped with a 4.4 to $4.8 \mathrm{~W}$ tungsten halogen lamp (Cole Parmer Instrument Co., Item No. 02-015850-000) capable of delivering a range of photon flux from 0 to $250 \mu \mathrm{mol}$ quanta $\mathrm{m}^{-2} \cdot \mathrm{s}^{-1}$. Irradiance levels delivered by the fiber optic light pipes were measured with a spherical quantum sensor (Biospherial Instruments QLS-1000) for all experimental combinations of filters and intensities.

\subsection{Intensity Tests}

Motile cells were simultaneously exposed to the three broad spectrum irradiance levels at near complete darkness, 50, 100, $250 \mu \mathrm{mol}$ quanta $\mathrm{m}^{-2} \cdot \mathrm{s}^{-1}$ at room temperature for $20 \mathrm{~min}$. Preliminary trials (data not shown) indicate that 20 minutes is adequate time for the cells to swim to all light sources but not to attach to petri dish surfaces.

\subsection{Spectral Tests}

Motile cells were simultaneously exposed to the three qualities of irradiance for 20 minutes each at low (50 $\left.\mu \mathrm{mol} \mathrm{m}{ }^{-2} \cdot \mathrm{s}^{-1}\right)$, medium $\left(100 \mu \mathrm{mol} \mathrm{m} \mathrm{m}^{-2} \cdot \mathrm{s}^{-1}\right)$, and high $\left(250 \mu \mathrm{mol} \mathrm{m} \mathrm{m}^{-2} \cdot \mathrm{s}^{-1}\right)$ irradiance intensities. Red, green, and blue plastic filters were each cut with a $1.7 \mathrm{~cm}$ diamcork borer and placed over one end of a fiber optic light pipe. The filters were scanned with a Vis-UV Diode array spectrophotometer (Hewlett Packard, 5428A). The irradiance ranges of 50,100 and $250 \mu \mathrm{mol} \mathrm{m} \mathrm{m}^{-2} \cdot \mathrm{s}^{-1}$ were selected based on the known photosynthetic parameters of U. fasciata [28].

\subsection{Statistical Analyses}

The subsequent statistical analyses were carried out using SAS, version 6.2. Normality was assessed with a $\rho$ less than 0.05 . When the data were normally distributed, comparisons quality and quantity of irradiance were made with the 1-way ANOVA (Duncan-Waller test) analysis. When the data were asymmetrical, the 1-way non-parametric analysis (Wilcox test) was used.

\section{Results}

\subsection{Spectral Ranges Designed by Filters}

The experimental spectral filters transmitted broad ranges of wavelengths, maxima for transmittance were 456, 518 and $\geq 710 \mathrm{~nm}$ for blue, green, and red filters, respectively. At $50 \%$ of maximal transmittance the width of blue 50, green 50, and red 50 spectral bands ranged from 398 to 524,462 to $578 \mathrm{~nm}$, and $\leq 660$ to infra-red, respectively. The area of transmittance of blue 50 green 50 and red 50 filters range from 490 to $550 \mathrm{~nm}$ wavelength where in enhance the photosynthesis [28] 13.33, 41.62 and 0 (Table 1). The ratio of transmittance of blue 50 and green 50 was 3.12. The total absorbance areas of blue, green and red filters were 227.26, 161.07 and 86.84 at range from 350 to $700 \mathrm{~nm}$. Approximate swimming speed of motile cell was $6.75 \pm 0.75 \mathrm{~cm} \mathrm{hr}^{-1}$.

\subsection{Quantity of Irradiance-Gametes}

The specific response of $U$. fasciata gametes to three levels of irradiance showed that gametes swim to brighter regions of the petri dishes. The response generally increased as irradiance level increased reaching a mean percentage (Table 2) of gametes at the highest irradiance $250 \mu \mathrm{mol} \mathrm{m}{ }^{-2} \cdot \mathrm{s}^{-1}$ (Table 2). The Chi-Square revealed significant differences between all 4 irradiance conditions $(\mathrm{DF}=3$, CHISQ $=101.34, \mathrm{p}>0.01)$. This relationship was generally held linearly $\left(Y=4.09 X+0.68, r^{2}=0.81, p>0.01\right)$. 
Table 1. Absorbance and transmittance of motile cells of $U$. fasciata and three filters (red, green and blue), and ratio of maximum photosynthesis (Ik \& Ic) and quantities of irradiance treatments $\left(50,100 \& 250 \mu \mathrm{mol} \cdot \mathrm{cm}^{2} \cdot \mathrm{s}^{-1}\right)$. Gamete: spore of Ik \& Ic $=99.5 \& 288.3: 61.5 \& 172.6$.

\begin{tabular}{|c|c|c|c|}
\hline Wavelength (nm) & $\begin{array}{c}350-700 \\
(50 \%)\end{array}$ & $\begin{array}{c}490-550 \\
(50 \%)\end{array}$ & $\begin{array}{c}510-550 \\
(50 \%)\end{array}$ \\
\hline $\begin{array}{c}\text { Red Filter } \\
\text { (Abs. Max. > } 650 \text { nm) }\end{array}$ & 86.84 & $0(0)$ & $0(0)$ \\
\hline $\begin{array}{c}\text { Green Filter } \\
(\text { Abs. Max. }=512 \mathrm{~nm} \text { ) }\end{array}$ & 161.07 & 87.55 (41.62) & 61.18 \\
\hline $\begin{array}{l}\text { Blue Filter } \\
\text { Abs. Max. = } 456 \mathrm{~nm}) \\
\text { Ratio }(\mathrm{B} / \mathrm{G})\end{array}$ & 227.26 & $\begin{array}{c}50.84(13.33) \\
1.72(3.12)\end{array}$ & $\begin{array}{c}24.47 \\
2.5\end{array}$ \\
\hline
\end{tabular}

Abs = absorbance spectrum; Max = Maxium.

Table 2. The specific responses of gamete and spore of Ulva fasciata to three levels of irradiance [standard deviation (SD), degree of freedom (DF) and Chi-square (CHISQ), Irradiance (Ir) parentheses]. Irradiance unit is $\mu \mathrm{mol} \mathrm{m}^{-2} \cdot \mathrm{s}^{-1}$.

\begin{tabular}{ccccc}
\hline Cells & $\begin{array}{c}\text { Gamete } \\
\text { (Ir/Ic or Ik) } \\
\text { Con }\end{array} \quad$ Ik = 288.3 Ic $=99.5$ & \multicolumn{2}{c}{ Spore } \\
\hline 50 & 0.173 & 0.5 & Ik $=172.6$ Ic $=61.5$ \\
100 & 0.347 & 1.01 & 0.289 & 0.8 \\
250 & 0.867 & 2.51 & 0.579 & 1.63 \\
\hline
\end{tabular}

\subsection{Quantity of Irradiance-Spores}

The specific response of $U$. fasciata spores to three levels of irradiance showed that spores swim to dark regions of the petri dishes (Table 2). The response had a mean percentage of spores in the dark. This avoidance of irradiance did not differ significantly over the three levels of irradiance (50, 100 and $\left.250 \mu \mathrm{mol} \mathrm{m}^{-2} \cdot \mathrm{s}^{-1}\right)(\mathrm{DF}=3$, CHISQ = 77.53, p > 0.01) (Table 2).

\subsection{Spectral Quality of Irradiance-Gametes}

The specific response of $U$. fasciata gametes to spectral irradiance less than Ic $\left(50 \mu \mathrm{mol} \mathrm{m}^{-2} \cdot \mathrm{s}^{-1}\right)$ showed that the greatest percentage of gametes swam to the green irradiance region, with the mean percentage of gametes reaching 32.07\% (Table 3). Blue irradiance was also selected by gametes over dark and red irradiance treatments (Table 3). The three groupings for mean values were statistically distinct (DF $=3, \mathrm{CHISQ}=100.92$, $\mathrm{p}>$ $0.01)$.

The specific response of $U$. fasciata gametes to a medium spectral irradiance (Ic $\leq 100 \mu \mathrm{mol} \cdot \mathrm{cm}^{-2} \cdot \mathrm{s}^{-1}<\mathrm{Ik}$ ) showed that the greatest percentage of gametes swam to the green irradiance region, with mean percentage of gametes reaching 23.26\% (Table 3). Dark and red irradiance again were not preferred by gametes (Table 3). The three groupings for mean values were statistically distinct (DF $=3$, ISQ = 78.75, p > 0.01).

The specific response of $U$. fasciata gametes to a high spectral irradiance $\left(250 \mu \mathrm{mol} \cdot \mathrm{cm}^{-2} \cdot \mathrm{s}^{-1} \approx \mathrm{Ik}\right)$ showed the greatest percentage of gametes swam to the green irradiance region with the mean percentage of gametes reaching 22.18\% (Table 3). Fewer gametes swam to the blue irradiance region than to green light. However, gametes were attracted to green irradiance compared to the other treatments (Table 3). The three groupings for mean values were statistically distinct $(\mathrm{DF}=3, \mathrm{CHISQ}=98.82, \mathrm{p}>0.01)$.

\subsection{Spectral Quality of Irradiance-Spores}

The specific response of $U$. fasciata spores to spectral irradiance intensity less than Ic $\left(50 \mu \mathrm{mol} \cdot \mathrm{cm}^{-2} \cdot \mathrm{s}^{-1} \approx \mathrm{Ic}\right)$ resulted in the greatest percentage of spores swam to the dark region (Table 3). Red, green and blue spectral irradiance were not preferred (Table 3 ). The two groupings for mean values were statistically distinct $(\mathrm{DF}=3$, 
Table 3. The specific responses of gamete and spore of Ulva fasciata to select spectral irradiance ranges (Irradiance unit is $\mu \mathrm{mol} \mathrm{m}{ }^{-2} \cdot \mathrm{s}^{-1} ; \mathrm{R}=$ Red filter, $\mathrm{G}=$ Green filter, $\mathrm{B}=$ Blue filter).

\begin{tabular}{|c|c|c|}
\hline $\begin{array}{c}\text { Irradiance } \\
\mu \mathrm{mol} \mathrm{m}{ }^{-2} \cdot \mathrm{s}^{-1}\end{array}$ & Gamete (\%) & Spore (\%) \\
\hline $50 \mathrm{R}$ & 3.8 & 2.1 \\
\hline G & 32.07 & 2.05 \\
\hline B & 13.1 & 1.67 \\
\hline $\mathrm{D}$ & 2.5 & 8.22 \\
\hline $100 \mathrm{R}$ & 4.14 & \\
\hline G & 23.26 & 1.8 \\
\hline B & 7.5 & 4.02 \\
\hline $\mathrm{D}$ & 2.5 & 2.1 \\
\hline$D$ & 2.5 & 7.39 \\
\hline $250 \mathrm{R}$ & 4.11 & 2.2 \\
\hline G & 22.18 & 3 \\
\hline B & 14.8 & 2.2 \\
\hline $\mathrm{D}$ & 3.21 & 6.24 \\
\hline
\end{tabular}

CHISQ $=51.69, \mathrm{p}>0.01)$.

The specific response of $U$. fasciata spores to a medium spectral irradiance intensity (Ic $<100 \mu \mathrm{mol} \mathrm{m}{ }^{-2} \cdot \mathrm{s}^{-1}<$ Ik) showed in the greatest percentage of spores again swam to the dark region, with the mean percentage of spores reaching $7.39 \%$ (Table 3 ) over the other treatments. The three groupings for mean values were statistically distinct $(\mathrm{DF}=3$, CHISQ $=60.78, \mathrm{p}>0.01)$.

The specific response of $U$. fasciata spores to a high spectral irradiance intensity (Ik $<250 \mu \mathrm{mol} \cdot \mathrm{m}^{-2} \cdot \mathrm{s}^{-1}$ ) showed the maximal number of spores swarm toward the dark region with the mean number of spore reaching $6.24 \%$ (Table 3). The two groupings for mean values were statistically distinct ( $\mathrm{DF}=3, \mathrm{CHISQ}=66.92, \mathrm{p}>$ $0.01)$.

\section{Discussion}

In a dynamic coastal environment, motile cells of Ulva fasciata simultaneously perceive different qualities and quantities of irradiance. These experiments worked to separate the potentially distinct roles of irradiance within ecologically and physiologically relevant ranges. Gametes and spores clearly have very distinct ecological strategies: gametes preferred the highest irradiance intensity $\left(250 \mu \mathrm{mol} \cdot \mathrm{m}^{-2} \cdot \mathrm{s}^{-1}\right)$ while spores preferred darkness. Gametes preferred broad-band blue-green irradiance while spores preferred darkness. These results have ecological implications for these life cycle stages. Gametes are likely to enhance the likelihood of gamete encounter and localized movements by swimming to subsurface irradiance levels of coastal environment. Spores are likely to enhance the probability of finding substratum by avoiding irradiance cues of any kind.

Surface waters where cells are exposed to broadband white light; however, as the spectral irradiance narrows with depth, and weighted with proportionally more blue-green light in green algae habitats. Irradiance entering into the marine environment changes not only in quantity, but also in quality. Natural irradiance, even in deep water, is broad-banded ( $\geq 10 \mathrm{~nm}$ ). The spectral composition of down welling flux changes progressively with increasing depth and turbidity because irradiance is differentially absorbed strongly and quickly. In order to select appropriate ecological positions, motile cells of Ulva fasciata rely on spectral intensity, but in surprisingly different ways for cells types (gametes and spores) that have similar pigment composition and metabolic rates for photosynthesis and respiration [28]. It is well known that to survive in marine environments, adult plants are harvest to broad spectral irradiance and possess photoacclimation mechanisms to adjust to light fluctuations [5]. The observed spectrally-neutral sporebehavioris somewhat counter-intuitive, and as such must lead to rapid settlement immediately upon release during the day. This rapid settlement response potentially limits dispersal of that cell type from the parent diploid thallus. The results of this behavior to irradiance have specific ecological implications for motile cells of $U$. fasciata. Ecologically, an egative-irradiance migration of the spore is thought to help the spore reach a suitable substrate more quickly, while the positive-irradiance migration of the gamete increases the probability of encountering appropriate opposite-gamete strains and potentially influencing dis- 
persal distances for resulting zygotes. The swimming speeds of motile algal cells (e.g. $U$. fasciata $\approx 6.75 \mathrm{~cm} \cdot \mathrm{hr}^{-1}$ ) may be slow in comparison to the water currents in the sea [32] [33] but they are substantial compared with other plankton (e.g. diatoms) and are likely to be important for localized movements such as gamete encounters or site selection prior to settlement. This ability to swim probably accounts for the high respiration rates measured by Beach et al. [28] and the early settled spores sustain a 37\% reduction in $\mathrm{R}$ declines. It is curious to consider that spores swim away from the irradiance that indirectly powers their swimming. These features differential behavior of gametes and spores underscores differences between algal planktonic cells and invertebrates. These distinctly different behaviors are likely to add to the success and dominance of this species with an isomorphic alternation of generations by providing 2 dispersal window's to span a wide range of marine environments.

Both types of motile cells for Ulva fasciata showed efficient photosynthesis [28] with enhanced light harvesting over wavelengths from 475 to $495 \mathrm{~nm}$ via absorbance by lutein and $\beta$-carotene [34]. The behavior by $U$. fasciata gametes favoring increasing irradiance of white light, as well as different spectral regions is strong evidence for light-harvesting by motile cells. The greatest response detected by these cells was for the most severely limiting intensity $(<\mathrm{Ic})$ and for those spectral components those cells effectively absorb for light-harvesting. The most effective light quality was broad band blue-green irradiance, followed by blue irradiance at high irradiance level.

For gametes syngamy and long range dispersal are important and, for spores, rapid settlement is most important by how rapidly they settle. Spores of Enteromorpha flexuosa have about two-fold higher rates of respiration than those observed for any cell type of the Ulva fasciata life-history or of the adult thallus for E. flexuosa [29]. If there are links between metabolic levels and behavior, one might expect that spores of E. flexuosa can swim faster and settle more quickly than those of $U$. fasciata. The highest Ic values of the Beach et al. study [29] came for spores of E. flexuosa, strongly suggesting that the more quickly those cells can settle, the more rapidly they can benefit from a reduced rate of respiration as was observed for settled spores of $U$. fasciata.

Photosynthetic performance is obviously an important factor potentially extending the length of the planktonic stage. The exact duration of spore or gamete viability in the planktonic stage is not known. All of the behaviors reported here suggest that photosynthetic behavior of motile cell rather than the particular photoreceptors respond to irradiance: spores were spectrally-neutral in their responses overall; gametes responded to increasing quantity (rather than low irradiance-typical photoreceptor react to low irradiance), and spectral signatures at all irradiances for which no known photoreceptors exist.

In summary, motile cells of Ulva fasciata were responsive to specific quantities and spectral qualities of irradiance, observations that are likely to be very important to ecological success and physiological strategies in varied dynamic irradiance environments. In this study several important insights were gained: 1 ) gametes respond to quantities and qualities of irradiance in such as way as to enhance the likelihood of gamete encounter and localized movements; 2) spores respond negatively to quantity and quality of irradiance in such a way as to enhance the probability of finding substratum; and 3) populations of haploid adults that come from these spore behaviors are likely to be patches of meiotically related adult in their genetic makeup because spores do not enter the plankton pool of settlers. Populations of diploid adults that come from gamete behaviors are likely to be more broadly dispersed and random in their genetic structure. These observations are likely to be very important for the ecological success of this species in the varied dynamic irradiance environments where it is found.

The levels of irradiance needed to saturate a species shows some correlation with habitat: intertidal species require 400 to $600 \mu \mathrm{mol} \cdot \mathrm{cm}^{-2} \cdot \mathrm{s}^{-1}$, upper and mid-subtidal species saturate with 150 to $250 \mu \mathrm{mol} \cdot \mathrm{cm}^{-2} \cdot \mathrm{s}^{-1}$ and deep-sublittoral species require less than $100 \mu \mathrm{mol} \cdot \mathrm{cm}^{-2} \cdot \mathrm{s}^{-1}[35]$.

\section{Acknowdgements}

This work was supported by the National Research Foundation of Korea by the Korean Government [20120453].

\section{References}

[1] Kirk, J.T.O. (1983) Light and Photosynthesis in Aquatic Ecosystems. Cambridge University Press, Cambridge.

[2] Han, T., Han, Y.-S., Kain, J.M. and Häder, D.-P. (2003) Thallus Differentiation of Photosynthesis, Growth, Reproduction, and UV-B Sensitivity in the Green Alga Ulva Pertusa (Chlorophyceae). Journal of Phycology, 39, 712-721. http://dx.doi.org/10.1046/j.1529-8817.2003.02155.x 
[3] Littler, M.M., Littler, D.S., Blairm, S.M. and Norris, J.N. (1985) Deepest Known Plant Life Is Discovered on an Uncharted Seamount. Sciences, 227, 57-59. http://dx.doi.org/10.1126/science.227.4682.57

[4] Dring, M.J. (1989) Light Harvesting and Pigment Composition in Marine Phytoplankton and Macroalgae. In: Herring, P.J., Campbell, A.K., Whitfield, M. and Maddock, L., Eds., Light and Life in the Sea, Cambridge University Press, Cambridge, 89-103.

[5] Halldal, P. (1958) Action Spectra of Phototaxis and Related Problems in Volvocales, Ulva-Gametes and Dinophyceae. Physiologia Plantarum, 11, 118-153. http://dx.doi.org/10.1111/j.1399-3054.1958.tb08432.x

[6] Christie, A.O. and Evans, L.V. (1962) Periodicity in the Liberation of Gametes and Zoospores of Enteromorpha intestinalis Link. Nature, 193, 193-194. http://dx.doi.org/10.1038/193193a0

[7] Jones, E.W. and Babb, M.S. (1968) The Motile Period of Swarmers of Enteromorpha intestinalis (L.) Link. British Phycological Bulletin, 3, 525-528. http://dx.doi.org/10.1080/00071616800650131

[8] Woodhead, P. and Moss, B. (1975) The Effect of Light and Temperature on Settlement and Germination of Enteromorpha. British Phycological Journal, 10, 269-272. http://dx.doi.org/10.1080/00071617500650281

[9] Amsler, C.D., Reed, D.C. and Neushul, M. (1992) The Microclimate Inhabited by Macroalgal Propagules. British Phycological Journal, 27, 253-270. http://dx.doi.org/10.1080/00071619200650251

[10] Cox, P.A. (1983) Search Theory, Random Motion, and the Convergent Evolution of Pollen and Spore Morphology in Aquatic Plant. The American Naturalist, 12, 9-13.

[11] Reed, D.C., Laur, D.R. and Ebeling, A.W. (1988) Variation in Algal Dispersal and Recruitment: The Importance of Episodic Events. Ecological Monographs, 58, 321-335. http://dx.doi.org/10.2307/1942543

[12] Nelson, T.A., Haberlin, K., Nelson, A.V., Ribaric, H., Hotchkiss, R., Van Alstyne, K.L., et al. (2008) Ecological and Physiological Controls of Species Composition in Green Macroalgal Blooms. Ecology, 89, 1287-1298. http://dx.doi.org/10.1890/07-0494.1

[13] Korbee, N., Figueroa, F.L. and Aguilera, J. (2005) Effect of Light Quality on the Accumulation of Photosynthetic Pigments, Proteins and Mycosporine-Like Amino Acids in the Red Alga Porphyra leucosticte (Bangiales, Rhodophyta). Journal of Photochemistry and Photobiology. B, Biology, 80, 157-173.

[14] Payri, C.E., Maritorena, S., Bizeau, C. and Rodiere, M. (2001) Photoacclimation in the Tropical Coralline Alga Hydrolithon onkodes (Rhodophyta, Corallinaceae) from a French Polynesian Reef. Journal of Phycology, 37, $223-234$. http://dx.doi.org/10.1046/j.1529-8817.2001.037002223.x

[15] Hader, D.P. and Reinecke, E. (1991) Phototactic and Polarotactic Responses of the Photosynthetic Flagellate Euglena gracilis. Acta Protozoologica, 30, 13-18.

[16] Duncan, M.J. and Foreman, R.E. (1980) Phytochrome-Mediated Stipe Elongation in the Kelp Nereocystis (Phaeophyceae). Journal of Phycology, 16, 138-142. http://dx.doi.org/10.1111/j.1529-8817.1980.tb03008.x

[17] Ruyters, G. (1988) Light-Stimulated Respiration in the Green Alga Dunaliella tertiolecta: Involvement of Ultraviolet/Blue-Light Phtoreceptor(s) and Phytochrome? Planta, 174, 422-425. http://dx.doi.org/10.1007/BF00959530

[18] Lopez-Figueoa, F. and Neill, F.X. (1989) Red-Light and Blue-Light Photoreceptors Controlling Chlorphyll a Snythesis in the Red Alga Porphyra umbilicalis and in the Green Alga Ulva rigida. Physiologia Plantarum, 76, 391-397. http://dx.doi.org/10.1111/j.1399-3054.1989.tb06209.x

[19] Engelmann, T.W. (1883) Farbeand Assimilation. Bot. Zeit., 41, 1-13.

[20] Berthold, G. (1882) Uber die verteilung der algenim Golf von Neapel nebst einem verzeichnis der bisher daselbst beobachten Arten. Mittheilungen aus der Zoologischen Station zu Neapel, 3, 393-536.

[21] Oltmanns, F. (1892) Uber die Kultur und Lebensbedinggungen der Meeresalgen. Jb. Wiss. Bot., 23, 349-440.

[22] Shepherd, S.A. and Sprigg, R.C. (1976) Substrate Sediments and Subtidal Ecology of Gulf St. Vincent and Investigator Strait. In: Twidale, C.R., Tyler, M.J. and Webb, B.P., Eds., Natural History of the Adelaide Region, Mar. Ecol. Pro. Ser., Royal Society of South Australia, Adelaide, 161-174.

[23] Anderson, J.M., Waldron, J.C. and Thorne, S.W. (1980) Chlorophyll-Protein Complexes of a Marine Green Alga, Caulerpa cactoides. Plant Science Letters, 17, 149-157. http://dx.doi.org/10.1016/0304-4211(80)90142-X

[24] Doty, M.S., Gilbert, W.J. and Abbott, I.A. (1974) Hawaiian Marine Algae from Seaweed of the Algal Ridge. Phycologia, 13, 245-357. http://dx.doi.org/10.2216/i0031-8884-13-4-345.1

[25] Yokohama, Y., Hirata, T., Misonou, T., Tanaka, J. and Yokochi, H. (1992) Distribution of Green Light-Harvesting Pigments, Siphonoxanthin and Siphonein, and Their Precursors in Marine Green Algae. App. J. Phycol., 40, 25-33.

[26] Figueroa, F.L., Conde-Alvarez, R. and Gomez, I. (2003) Relations between Electron Transport Rates Determined by Pulse Amplitude Modulated Chlorophyll Fluorescence and Oxygen Evolution in Macroalgae under Different Light 
Conditions. Photosynthesis Research, 75, 259-275. http://dx.doi.org/10.1023/A:1023936313544

[27] Amsler, C.D. and Neushul, M. (1991) Photosynthetic Physiology and Chemical-Composition of the Kelps Macrocystis pyrifera, Nereocystis leutkeana, Laminaria farlowii, and Pterygophora californica (Phaeophyceae). Journal of Phycology, 27, 26-34. http://dx.doi.org/10.1111/j.0022-3646.1991.00026.x

[28] Bell, G. (1997) The Evolution of the Life Cycle of Brown Seaweeds. Biological Journal of the Linnean Society, 60, 2138. http://dx.doi.org/10.1111/j.1095-8312.1997.tb01481.x

[29] Edwards, M.S. (2000) The Role of Alternate Life-History Stages of a Marine Macroalga: A Seed Bank Analogue? Ecology, 81, 2404-2415. http://dx.doi.org/10.1890/0012-9658(2000)081[2404:TROALH]2.0.CO;2

[30] Beach, K.C., Borgeas, H.B., Nishimura, N.J. and Smith, C.M. (1997) In Vivo Absorbance Spectra in the Ecophysiology of Reef Macroalgae. Coral Reefs, 16, 21-28. http://dx.doi.org/10.1007/s003380050055

[31] American Public Health Association (APHA) (1976) Standard Methods for the Examination of Water and Wastewater. 14th Edition, American Public Health Association, Washington DC, 1193.

[32] Suto, S. (1950) Studies on a Counting Method of Spores of Seaweeds in the Sea. Bulletin of the Japanese Society for the Science of Fish, 15, 674-677. http://dx.doi.org/10.2331/suisan.15.674

[33] North, W.J. (1972) Mass Cultured Macrocystis as a Means of Increasing Kelp Stands in Nature. Proceedings of International Symposium on Seaweed Research, 7, 394-399.

[34] Shin, H.W. and Smith, C.M. (1996) Characterization of Light-Harvesting Pigments in Spores of Ulva fasciata Delile. Algae, 11, 309-315.

[35] Luning, K. (1981) Light. In: Lobban, C.S. and Wynne, M.J., Eds., The Biology of Seaweeds, Blackwell Scientific Publications, Oxford, 326-355. 
Scientific Research Publishing (SCIRP) is one of the largest Open Access journal publishers. It is currently publishing more than 200 open access, online, peer-reviewed journals covering a wide range of academic disciplines. SCIRP serves the worldwide academic communities and contributes to the progress and application of science with its publication.

Other selected journals from SCIRP are listed as below. Submit your manuscript to us via either submit@scirp.org or Online Submission Portal.
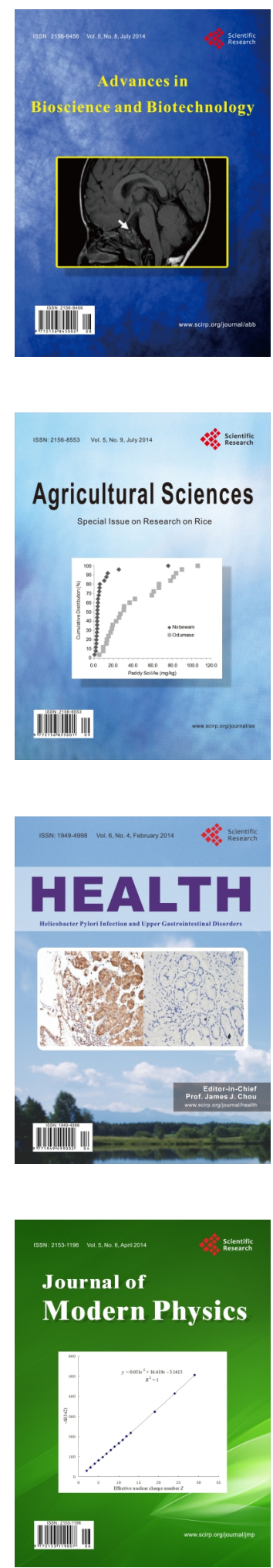
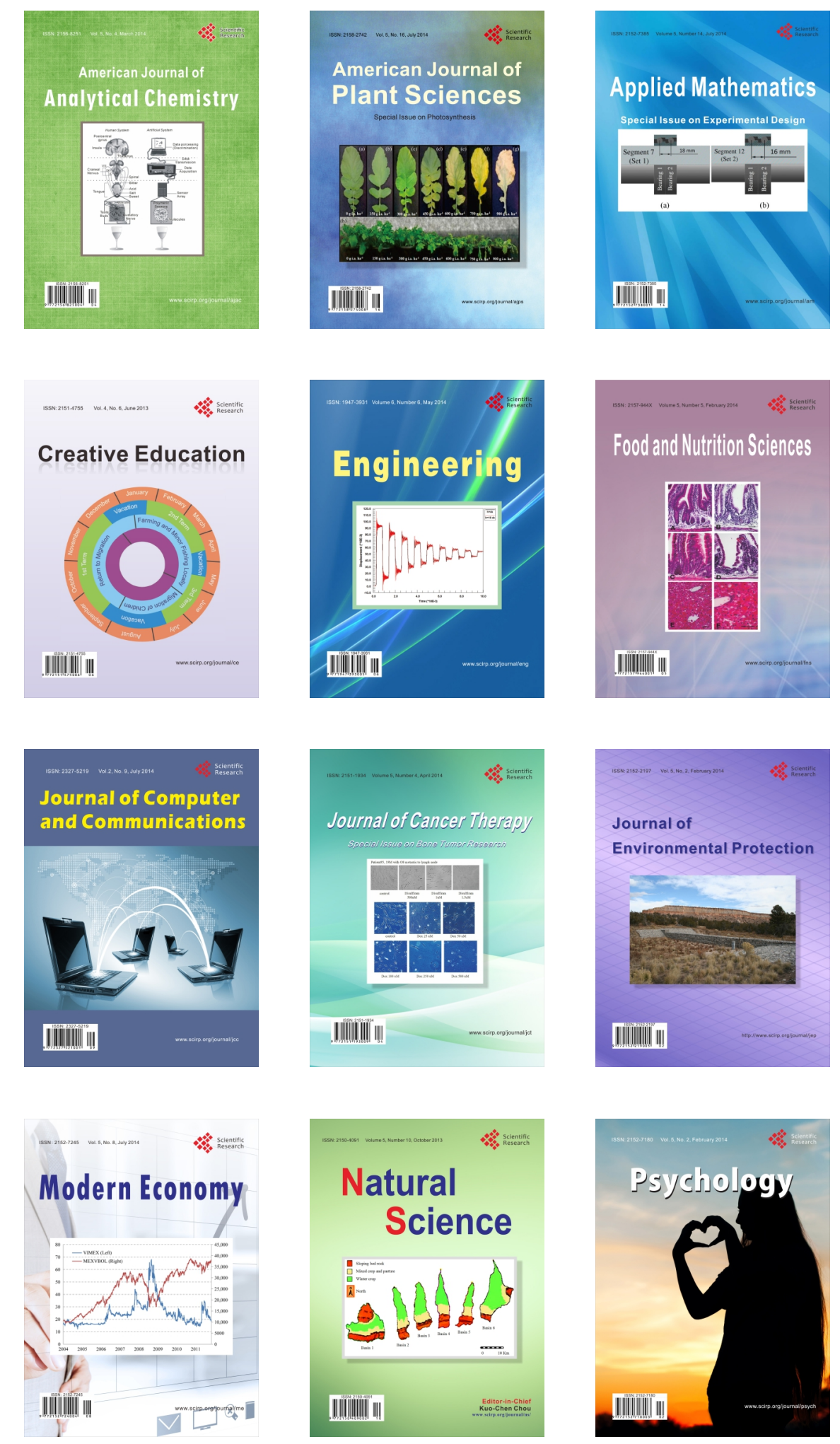